\title{
Relokasi Permukiman Warga Bantaran Sungai Ciliwung di Provinsi Jakarta
}

\author{
Nur Aini Fitrianti \\ University of Jember, Indonesia \\ nurainifitrianti19@gmail.com \\ Nurul Laili Fadhilah \\ University of Jember, Indonesia \\ nulifadh@gmail.com
}

\begin{abstract}
As the population grows rapidly, more and more illegal settlements are built on state land which is actually prohibited to establish shelter, especially in the Ciliwung River area. The Jakarta Provincial Government has a policy to relocate the residents of Ciliwung River to ensure that the river and Ciliwung river functions are back to normal. The government provides for relocation with the construction of flats so they can have a more decent life. The problem is whether the implementation of relocation of settlements Ciliwung River river residents are in accordance with Law No. 2 of 2012 on Land Procurement for the Public Interest and Regional Regulation of the Special Capital Province of Jakarta No. 1 of 2012 on Spatial Plans. The method used in this research is using normative juridical research type. This study concludes that the implementation of the relocation of the settlement is in accordance with Law No. 2 of 2012 on Land Procurement for the Public Interest and Regional Regulation of the Province of Jakarta Capital Special Region No. 1 of 2012 on Spatial Planning
\end{abstract}

KEYWORDS: Local Government, Relocation, River Basin Settlements.

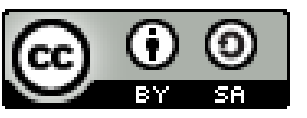

Copyright $\odot 2018$ by Author(s)

This work is licensed under a Creative Commons Attribution-ShareAlike 4.0 International License. All writings published in this journal are personal views of the authors and do not represent the views of this journal and the author's affiliated institutions.

\section{HOW TO CITE:}

Fitrianti, Nur Aini \& Nurul Laili Fadhilah. "Relokasi Permukiman Warga Bantaran Sungai Ciliwung di Provinsi Jakarta” (2018) 5:2 Lentera Hukum 293-306.

Submitted: January 26, 2018 Revised: March 05, 2018 Accepted: July 31, 2018 


\section{PENDAHULUAN}

Tanah mempunyai arti penting dalam kehidupan manusia. Kebutuhan tanah di pedesaan maupun di perkotaan terus meningkat, sedangkan masalah yang dihadapi umumnya di kota-kota besar adalah bersumber dari pertumbuhan penduduk maupun pertumbuhan karena urbanisasi. Selain karena pertumbuhan penduduk, disebabkan pula oleh penghasilan masyarakat perkotaan tidak seimbang dengan harga rumah dan biaya hidup di kota. Mereka dipaksa bertempat tinggal secara berhimpi-himpitan di permukiman-permukiman kumuh yang mengakibatkan turunnya kualitas lingkungan hidup.

Dalam hal ini, negara memiliki kewajiban melakukan pengelolaan untuk selanjutnya sebesar-besarnya peruntukan demi kemakmuran rakyat seperti yang telah dituangkan dalam Pasal 33 ayat (3) Undang-Undang Dasar Negara Republik Indonesia Tahun 1945 (UUD 1945) yang menegaskan bahwa bumi dan air dan kekayaan alam yang terkandung di dalamnya dikuasai oleh negara dan dipergunakan untuk sebesarbesarnya kemakmuran rakyat. Pengelolaan yang dilakukan pemerintah merupakan penataan ruang dalam bentuk relokasi permukiman. Relokasi sebenarnya tidak hanya terjadi di Jakarta saja tapi sudah merambah ke daerah lain seperti di Surabaya dan kotakota lainnya. Seperti contohnya yaitu Jakarta yang merupakan Ibukota Negara Indonesia dengan jumlah penduduk yang rata-rata merupakan pendatang. Penduduk yang berpenghasilan tinggi dapat membangun maupun menyewa perumahan dan permukiman dengan tempat yang strategis. Sedangkan untuk penduduk yang berpenghasilan rendah maupun yang tidak berpenghasilan, akan tinggal di daerah yang kotor, liar dan tidak sesuai dengan peruntukannya sebagai tempat tinggal seperti bantaran Sungai Ciliwung yang tidak hanya mengalir di Kota Jakarta, tetapi juga daerah Depok dan Bogor.

Pemerintah Provinsi Jakarta melakukan pengadaan tanah sebagai bentuk pengelolaan tanah untuk mewujudkan kesejahteraan dan kemakmuran masyarakat Jakarta. Masyarakat yang tinggal di bantaran Sungai Cilliwung tidak memiliki izin yang sah untuk tinggal karena merupakan tanah negara yang tidak boleh dibangun tempat tinggal dan peruntukannya bukan untuk tempat tinggal. Pengadaan tanah ini bertujuan agar Sungai Ciliwung yang menjadi penyebab banjir berfungsi normal kembali. Penyebab banjir ini dikarenakan sempitnya aliran sungai yang banyak dibangun tempat tinggal sehingga mengakibatkan daerah bantaran sungai tersebut menjadi kumuh dan kotor. Daerah bantaran sungai yang kumuh dan kotor ini tidak sesuai dengan rencana tata ruang wilayah yang diatur oleh Pemerintah Provinsi Jakarta.

Masyarakat bantaran Sungai Ciliwung yang tempat tinggalnya dijadikan objek pengadaan tanah, wajib diberikan ganti rugi oleh pemerintah demi mewujudkan asas keadilan yang telah diatur oleh undang-undang. Pelaksanaan relokasi yang dilakukan oleh pemerintah harus sesuai dengan prinsip maupun asas relokasi yang sudah diatur dalam Undang-Undang Nomor 12 Tahun 2012 tentang Pengadaan Tanah Bagi Pembangunan Untuk Kepentingan Umum dan Peraturan Daerah Provinsi Daerah Khusus Ibukota Jakarta Nomor 1 Tahun 2012 tentang Rencana Tata Ruang Wilayah. 
Asas-asas ini dilakukan dengan tujuan agar tidak terdapat pihak-pihak yang dirugikan atas tanahnya.

Berdasarkan permasalahan tersebut, penelitian ini perlu menganalisis mengenai pelaksanaan relokasi permukiman bantaran Sungai Ciliwung Daerah Khusus Ibukota Jakarta apakah sudah sesuai dengan Undang-Undang Nomor 12 Tahun 2012 tentang Pengadaan Tanah Bagi Pembangunan Untuk Kepentingan Umum dan Peraturan Daerah Provinsi Daerah Khusus Ibukota Jakarta Nomor 1 Tahun 2012 tentang Rencana Tata Ruang Wilayah.

\section{PELAKSANAAN RELOKASI PERMUKIMAN WARGA BANTARAN SUNGAI CILIWUNG}

Tanah merupakan kebutuhan yang sangat penting bagi kehidupan manusia. Pentingnya arti tanah bagi kehidupan manusia ialah karena kehidupan manusia itu sama sekali tidak dapat dipisahkan dari tanah. Mereka hidup di atas tanah dan memperoleh bahan pangan dengan cara mendayagunakan tanah. Hal ini diatur dalam Pasal 33 ayat (3) Undang-Undang Dasar Negara Republik Indonesia Tahun 1945 yaitu bumi dan air dan kekayaan alam yang terkandung di dalamnya dikuasai oleh negara dan dipergunakan untuk sebesar-besarnya kemakmuran rakyat.

Dari tahun ke tahun kebutuhan akan tanah dan ruang akan selalu meningkat. Hal ini semakin didukung dengan adanya peningkatan jumlah penduduk. Karena terlalu banyaknya atau terlalu pesatnya kelahiran manusia maka kemampuan tanah untuk menyediakan prasarana dan sarana kehidupannya akan sangat kurang, sehingga penderitaan dan kesengsaraan hidup manusia akan terjadi. ${ }^{1}$ Untuk mengatasi keadaan tersebut yang belum menimpa bangsa Indonesia, maka masyarakat harus memperhatikan hukum yang berlaku agar keseimbangan prasarana dan sarana kehidupan dengan perkembangan manusianya dapat selalu terjamin dengan baik. ${ }^{2}$ Seperti pada permukiman kumuh di bantaran Sungai Ciliwung, Daerah Khusus Ibukota Jakarta. Permukiman yang tidak mempunyai sarana maupun prasarana yang memadai tersebut merupakan tanah negara yang harus dipergunakan sebaik-baiknya berdasarkan fungsinya dan dikelola oleh negara demi kemakmuran masyarakat Indonesia.

Sebagai salah satu sungai terbesar yang bermuara di Jakarta, sungai Ciliwung sering menimbulkan banjir akibat meluapnya debit air sungai. Bagian hilir sungai Ciliwung telah terjadi penyempitan aliran sungai yang disebabkan oleh banyaknya perumahan ilegal yang berdiri di bantaran sungai Ciliwung. Banyaknya permasalahan yang terdapat pada sungai Ciliwung ini turut berdampak pada kesejahteraan warga Jakarta pada umumnya. Untuk itu, perlu adanya upaya perbaikan kualitas sungai Ciliwung, baik untuk kualitas sungainya itu sendiri maupun kualitas lingkungan sekitar sungai Ciliwung. Banyaknya perumahan ilegal di bantaran Sungai Ciliwung

Ibid at 3.

Ibid at 4 . 
perlu dilakukan penataan lebih lanjut. Hal ini dapat dilakukan melalui penataan kota yang lebih baik diharapkan kawasan permukiman kumuh dapat diperbaiki untuk dapat meningkatkan kualitas hidup masyarakat sehingga dapat membantu memberantas kemiskinan kota. ${ }^{3}$

Sehubungan dengan hal itu, Pemerintah Provinsi Jakarta mengadakan pengadaan tanah yang terdapat dalam Pasal 1 angka 2 Undang-Undang Nomor 2 Tahun 2012 tentang Pengadaan Tanah Bagi Pembangunan Untuk Kepentingan umum yaitu pengadaan tanah adalah kegiatan menyediakan tanah dengan cara memberi ganti kerugian yang layak dan adil kepada pihak yang berhak. Dalam undang-undang ini pengadaan tanah adalah untuk kepentingan umum, artinya menyediakan tanah bagi pelaksanaan pembangunan guna meningkatkan kesejahteraan dan kemakmuran bangsa, negara, dan masyarakat dengan tetap menjamin kepentingan hukum pihak yang berhak. Pengadaan tanah untuk kepentingan umum diselenggarakan oleh pemerintah. Masyarakat wajib melepaskan tanahnya pada saat pelaksanaan pengadaan tanah untuk kepentingan umum setelah pemberian ganti kerugian yang layak dan adil atau berdasarkan putusan pengadilan yang telah memperoleh kekuatan hukum tetap. ${ }^{4}$

Salah satu kegiatan pemerintah yang sesuai adalah dengan pelaksanaan relokasi permukiman warga bantaran Sungai Ciliwung ke tempat yang memiliki prasarana, sarana dan utilitas umum yang lebih layak. Dengan adanya relokasi, maka fungsi Sungai Ciliwung akan kembali normal agar tidak terjadi banjir dan penduduk bantaran Sungai Ciliwung akan diberikan tempat tinggal yang baru sebagai ganti rugi. Sehingga tanah negara yang terdapat di bantaran Sungai Ciliwung tersebut dapat dipergunakan sebaik-baiknya demi kepentingan masyarakat.

Pengadaan tanah yang dilakukan oleh pemerintah daerah tersebut adalah berupa relokasi permukiman kumuh yang terdapat di bantaran Sungai Ciliwung ke permukiman yang mempunyai sarana dan prasarana yang lebih memadai agar warga yang dahulu tinggal di bantaran sungai mendapatkan kehidupan yang layak, aman, dan tenteram. Hal ini sesuai dengan Pasal 10 huruf o Undang-Undang Nomor 2 Tahun 2012 yaitu tanah untuk kepentingan umum digunakan untuk pembangunan penataan permukiman kumuh perkotaan dan/atau konsolidasi tanah, serta perumahan untuk masyarakat berpenghasilan rendah dengan status sewa. Permukiman kumuh yang terdapat di bantaran Sungai Ciliwung harus dilakukan penataan kembali dengan tujuan untuk meningkatan kualitas lingkungan dan pemeliharaan sumber daya alam dengan melibatkan partisipasi aktif masyarakat.

Pelaksanaan relokasi yang merupakan pembangunan nasional bagi kepentingan umum bertujuan untuk mewujudkan masyarakat yang adil dan makmur yang merata,

Christy Vidiyanti, Studi Kasus: Bantaran Sungai Ciliwung Segmen Kampung Melayu Sustainable Waterfront Develepmont sebagai Strategi Penataan Kembali Kawasan Bantaran Sungai (ITB,Sekolah Arsitektur, Perencanaan, dan Pengembangan Kebijakan, 2014) at 1

4 Unit Jaringan Dokumentasi dan Informasi Hukum BPK RI Perwakilan Provinsi Kepulauan Bangka Belitung (Jakarta, Unit Dokumentasi dan Informasi Hukum BPK RI Perwakilan Provinsi Kepulauan Bangka Belitung, 2014) online: http://pangkalpinang.bpk.go.id/wpcontent/uploads /2014/12/FUNGSI-SOSIAL-HAK-ATAS-TANAH.pdf at 4. 
materiil dan spiritual berdasarkan Pancasila. Pembangunan nasional adalah upaya untuk meningkatkan seluruh aspek kehidupan masyarakat, bangsa dan negara yang sekaligus merupakan proses pengembangan keseluruhan sistem penyelenggaraan negara untuk mewujudkan tujuan nasional. ${ }^{5}$

Dalam melaksanakan relokasi permukiman bantaran Sungai Ciliwung diperlukan kesesuaian dengan faktor-faktor penting yang perlu dipertimbangkan dalam pengadaan tanah untuk kebutuhan proyek-proyek pembangunan. Faktor-faktor tersebut antara lain Pengadaan tanah untuk proyek-proyek pembangunan harus memenuhi syarat tata ruang dan tata guna tanah. ${ }^{6}$ Penggunaan tanah juga tidak boleh mengakibatkan kerusakan atau pencemaran terhadap kelestarian alam dan lingkungan. ${ }^{7}$ Selanjutnya adalah penggunaan tanah tidak boleh mengakibatkan kerugian masyarakat dan kepentingan pembangunan. ${ }^{8}$

Relokasi juga harus mempertimbangkan bahwa penerima dampak relokasi merupakan pihak yang dinilai rentan (vulnerable person). Dengan mempertimbangkan hal itu, maka dalam pelaksanaan relokasi harus mengikuti beberapa prinsip-prinsip. Prinsip-prinsip tersebut meliputi pemindahan bersifat sukarela, penerima dampak mendapatkan penghidupan yang setara atau lebih baik dari sebelum relokasi, dan penerima dampak mendapatkan kompensasi penuh selama proses transisi dan meminimalisir kerusakan jaringan sosial dan peluang ekonomi. ${ }^{9}$ Selain itu, prinsip tersebut juga mencakup peluang pengembangan bagi penerima dampak, demokratis, partisipatioris, terbuka dan akuntabel serta kemandirian dan keberlanjutan.

Dengan adanya prinsip-prinsip tersebut, relokasi harus dilaksanakan sesuai prinsip-prinsip yang berlaku agar mendapatkan penghidupan yang setara atau lebih baik dari sebelum relokasi. Penduduk yang direlokasi adalah semua penduduk yang tinggal didaerah bantaran Sungai Ciliwung yang tidak memiliki kemampuan ekonomi yang cukup. Pemerintah membantu penduduk tersebut untuk memperbaiki kondisi sosial ekonomi mereka dengan cara memindahkan tempat tinggal yang tidak layak ke tempat tinggal yang baru berupa rumah susun yang telah disediakan pemerintah sesuai tata ruang yang berlaku. Pelaksanaan relokasi ini juga harus menganut prinsip keberlanjutan yang dimana relokasi harus terus dilakukan agar kondisi perkotaan tertata sesuai peraturan perundang-undangan yang berlaku. Sungai Ciliwung yang selalu menjadi penyebab banjir di provinsi Daerah Khusus Ibukota Jakarta menjadi normal sesuai fungsinya sebagai daerah resapan air saat hujan. Sehingga tujuan dari relokasi itu akan tercapai apabila dilaksanakan sesuai dengan prinsip-prinsip relokasi.

Agar pelaksanaan relokasi membawa kemakmuran, kebahagiaan dan keadilan bagi negara dan rakyat terutama dalam rangka mencapai masyarakat yang adil dan

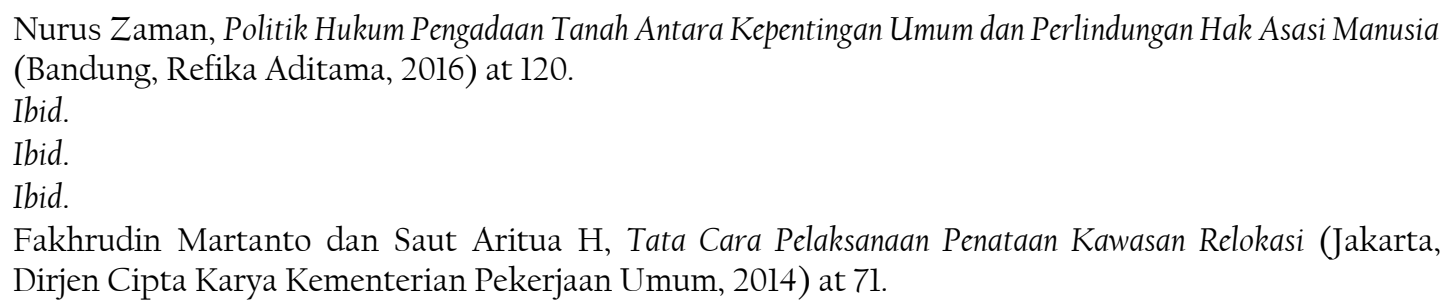


makmur, pemerintah menyediakan ganti kerugian untuk penduduk berupa rumah susun agar mereka tidak tinggal di bantaran Sungai Ciliwung. Tujuan pemerintah mengadakan relokasi adalah agar Sungai Ciliwung berfungsi normal kembali. Karena pemerintah melakukan relokasi dan normalisasi sungai maka aliran Sungai Ciliwung saat ini sudah berjalan normal kembali. Sebelumnya aliran Sungai Ciliwung menjadi sempit karena kumuhnya permukiman warga dan banyaknya warga yang membuang sampah sembarangan ke sungai sehingga aliran sungai tidak berfungsi normal dan menyebabkan banjir. Setelah Sungai Ciliwung berfungsi normal kembali, para warga dapat merasakan kenyamanan dan kesejahteraan yaitu berupa berkurangnya terjadi banjir karena Sungai Ciliwung sudah berjalan normal kembali dan mendapatkan tempat tinggal yang legal dan lebih layak.

Tujuan relokasi adalah agar tidak adanya banjir karena Sungai Ciliwung sudah berfungsi normal kembali dan mendapatkan tempat tinggal yang legal dan lebih layak sehingga masyarakat akan hidup lebih sejahtera. Selain itu juga agar masyarakat mempunyai tempat tinggal dan fasilitas MCK yang layak, meningkatkan kemampuan sosial ekonomi warga, kesehatan warga terjamin karena tidak tinggal di permukiman kumuh, agar fungsi sungai sebagai penampung air kembali seperti semula dan meningkatkan kelestarian sumber daya alam perkotaan Sesuai dengan tujuan dari pengadaan tanah yang terdapat dalam Pasal 3 Undang-Undang Nomor 2 Tahun 2012 yaitu bertujuan menyediakan tanah bagi pelaksanaan pembangunan guna meningkatkan kesejahteraan dan kemakmuran bangsa, negara, dan masyarakat dengan tetap menjamin kepentingan hukum pihak yang berhak.

Pelaksanaan relokasi permukiman bantaran Sungai Ciliwung tersebut harus sesuai dengan asas-asas yang terdapat dalam Pasal 2 Undang-Undang Nomor 2 Tahun 2012 tentang Pengadaan Tanah Bagi Pembangunan Untuk Kepentingan umum. Asasasas tersebut dimaksudkan untuk melindungi hak setiap orang atas tanahnya agar tidak dilanggar atau dirugikan ketika berhadapan dengan keperluan negara atas tanah untuk pembangunan bagi kepentingan umum. Asas kemanusiaan adalah asas yang harus memberikan perlindungan serta penghormatan terhadap hak asasi manusia, harkat dan martabat setiap warga negara dan penduduk Indonesia secara proporsional. Berdasarkan Pembukaan alinea ke-4 Undang-Undang Dasar Negara Republik Indonesia Tahun 1945, terdapat teori perlindungan hukum yang menyatakan bahwa melindungi segenap bangsa dan seluruh tumpah darah Indonesia. Perlindungan hukum menjadi kebutuhan bagi masyarakat agar segala bentuk hak yang melekat pada masyarakat itu dapat digunakan secara baik, meskipun pada sisi yang lain masyarakat juga memiliki kewajiban yang harus dilaksanakan juga. Konsep perlindungan hukum terkait dengan pengadaan hak atas tanah tidak hanya bagaimana pemberian ganti kerugian bagi pihak yang berjalan dengan baik. Dengan demikian pemerintah sebelum melakukan pengadaan tanah seharusnya memperjelas status tanah terkait alas haknya, sehingga pemberian ganti kerugian tidak dapat dipermainkan termasuk bagi warga 
yang tidak memiliki alas hak tersebut disamakan dengan warga yang sudah memiliki alas hak ketika pengadaan tanah dilaksanakan. ${ }^{10}$

Seluruh kegiatan pengadaan tanah terutama dalam pelaksanaan relokasi permukiman, warga permukiman bantaran Sungai Ciliwung tersebut mendapatkan ganti rugi yang mana diatur dalam Pasal 33 Undang-Undang Nomor 2 Tahun 2012 yaitu penilaian besarnya nilai Ganti Kerugian oleh Penilai sebagaimana dimaksud dalam Pasal 32 ayat (1) dilakukan bidang per bidang tanah, meliputi tanah, ruang atas tanah dan bawah tanah, bangunan, tanaman, benda yang berkaitan dengan tanah; dan/atau kerugian lain yang dapat dinilai.

Dalam menyelenggarakan pengadaan tanah untuk kepentingan umum harus sesuai dengan asas kemanfaatan yang pada prinsipnya harus dapat memberikan manfaat bagi semua pihak. Pengadaan tanah untuk kepentingan umum dapat terwujud sehingga pembangunan dapat dilaksanakan sesuai dengan rencana untuk berbagai fasilitas kepentingan umum. Di samping itu, pihak masyarakat pemilik tanah dapat diberikan ganti rugi yang layak atau dapat diberikan tanah pengganti dan permukiman kembali seperti yang diatur dalam Pasal 36 Undang-Undang Nomor 2 Tahun 2012, sehingga tingkat kehidupan sosial ekonominya dapat menjadi lebih baik atau setidaknya tidak menjadi lebih miskin dari sebelum tanah tersebut dicabut. Sehingga pada akhirnya kegiatan pengadaan tanah untuk pembangunan dapat bermanfaat bagi masyarakat sekitar. ${ }^{\text {ll }}$ Maka dari itu dengan diadakannya asas-asas dalam menyelenggarakan relokasi, akan mencapai kesejahteraan bagi masyarakat Indonesia.

Jadi dalam pelaksanaan relokasi permukiman warga bantaran Sungai Ciliwung yang merupakan program pemerintah sesuai dengan pengadaan tanah untuk kepentingan umum karena tujuan dari relokasi ini ditujukan demi kemakmuran dan kesejahteraan masyarakat yaitu agar Sungai Ciliwung berfungsi normal sehingga tidak menyebabkan banjir dan agar masyarakat yang tinggal di permukiman kumuh bantaran sungai mendapatkan tempat tinggal yang lebih layak.

\section{RELOKASI PERMUKIMAN WARGA BERDASARKAN PERATURAN DAERAH PROVINSI JAKARTA TENTANG RENCANA TATA RUANG WILAYAH}

Permukiman adalah kawasan hunian yang mempunyai sarana, prasarana dan utilitas umum dikawasan perkotaan atau pedesaan. Berdasarkan Pasal 1 angka 5 UndangUndang Nomor 1 Tahun 2011 tentang Perumahan dan Kawasan Permukiman, permukiman adalah bagian dari lingkungan hunian yang terdiri atas lebih dari satu satuan perumahan yang mempunyai prasarana, sarana, utilitas umum, serta mempunyai penunjang kegiatan fungsi lain di kawasan perkotaan atau kawasan perdesaan. Sedangkan pada Pasal 1 angka 60 Peraturan Daerah Provinsi Daerah Khusus Ibukota Jakarta Nomor 1 Tahun 2012 Tentang Rencana Tata Ruang Wilayah, kawasan

10 Nurus Zaman, supra note, at 195-196.

Il Achmad Rubaie, Hukum Pengadaan Tanah Untuk Kepentingan Umum (Surabaya, Bayumedia, 2007) at 32. 
permukiman adalah bagian dari lingkungan hidup di luar kawasan lindung berupa kawasan perkotaan yang berfungsi sebagai lingkungan tempat tinggal atau lingkungan hunian dan tempat kegiatan yang mendukung perikehidupan dan penghidupan.

Terdapat banyak permukiman yang tidak mempunyai prasarana, sarana maupun utilitas umum yang memadai, salah satunya adalah permukiman yang terdapat di bantaran Sungai Ciliwung Ibukota Jakarta. Permukiman tersebut merupakan permukiman kumuh yang berdiri diatas bantaran sungai. Pemerintah Ibukota Jakarta melarang masyarakat untuk tinggal atau membangun permukiman di daerah bantaran sungai. Sungai yang seharusnya sebagai daerah resapan air, tidak lagi berfungsi normal karena terdapat banyaknya permukiman kumuh yang mengakibatkan sempitnya aliran sungai.

Daerah bantaran sungai menurut Peraturan Pemerintah Nomor 38 Tahun 2011 tentang Sungai, termasuk dalam garis sempadan sungai yaitu garis maya di kanan dan kiri sungai yang ditetapkan untuk menjaga fungsinya sebagai jalan air. Jika kondisi daerah yang berada di garis sempadan sungai ini terjaga, maka sungai akan mampu menjaga lingkungan di sekitarnya dari bahaya banjir dan longsor. Oleh sebab itu, Pemerintah Provinsi DKI Jakarta memiliki program normalisasi sungai. Usaha tersebut dilakukan dengan melakukan pengerukan daerah aliran sungai yang mengalami pendangkalan, pembersihan sampah, serta penertiban bangunan dan aktivitas warga di sekitar sungai untuk proses pelebaran dan perbaikan lingkungan sekitar aliran sungai. ${ }^{12}$

Maka dari itu negara memberikan wewenang kepada pemerintah untuk menyelenggarakan penataan ruang agar tidak ada lagi permukiman kumuh dibantaran sungai dan fungsi sungai sebagai daerah resapan air kembali normal, hal ini sesuai dengan Pasal 7 Undang-Undang Nomor 26 Tahun 2007 tentang Penataan Ruang.

Pemanfaatan ruang menurut Pasal 1 angka 14 Undang-Undang Nomor 26 Tahun 2007 tentang Penataan Ruang adalah upaya untuk mewujudkan struktur ruang dan pola ruang sesuai dengan rencana tata ruang melalui penyusunan dan pelaksanaan program beserta pembiayaannya. Dalam Pasal 239 huruf a angka 3 Peraturan Daerah Provinsi Daerah Khusus Ibukota Jakarta Nomor 1 Tahun 2012 Tentang Rencana Tata Ruang Wilayah dijelaskan bahwa masyarakat dilarang untuk memanfaatkan ruang tanpa izin pemanfaatan ruang di lokasi yang tidak sesuai peruntukan. Maka dari itu pemerintah melaksanakan relokasi di wilayah bantaran Sungai Ciliwung karena masyarakat membangun rumah tanpa izin pemerintah, karena bantaran Sungai merupakan tanah milik negara yang tidak boleh di manfaatkan untuk keperluan tempat tinggal. Relokasi yang dilaksanakan pemerintah Ibukota Jakarta yaitu berupa penutupan lokasi, pembongkaran bangunan, pemulihan fungsi ruang dan pemindahan sarana, prasarana dan utilitas umum yang terdapat dalam permukiman kumuh bantaran Sungai Ciliwung ke permukiman yang lebih memadai.

Penataan ruang yang dilaksanakan Pemerintah Provinsi Jakarta memiliki tujuan yang terdapat dalam Pasal 5 huruf a Peraturan Daerah Provinsi Daerah Khusus Ibukota

12 Jakarta Smart City, Rumah Susun dan Normalisasi Ciliwung, http://smartcity.jakarta.go.id/blog/123/r umah-susun-dan-normalisasi-ciliwung, 2014, at 1. 
Jakarta Nomor 1 Tahun 2012 Tentang Rencana Tata Ruang Wilayah, yaitu terciptanya ruang wilayah yang menyediakan kualitas kehidupan kota yang produktif dan inovatif. Untuk mewujudkan tujuan tersebut pemerintah melakukan relokasi permukiman kumuh bantaran Sungai Ciliwung ke permukiman yang memiliki prasarana, sarana maupun utilitas umum yang lebih memadai agar dapat mewujudkan kota yang aman, nyaman dan tentram. Hal tersebut sesuai dengan Pasal 5 huruf a Peraturan Daerah Provinsi Daerah Khusus Ibukota Jakarta Nomor 1 Tahun 2012 Tentang Rencana Tata Ruang Wilayah, yaitu terwujudnya pelayanan prasarana dan sarana kota yang berkualitas, dalam jumlah yang layak, berkesinambungan, dan dapat diakses oleh seluruh warga Jakarta.

Selain memanfaatkan bantaran sungai untuk tempat tinggal secara illegal, masyarakat daerah bantaran Sungai Ciliwung juga membangun tempat tinggalnya di daerah yang tidak sesuai karena bantaran sungai merupakan tanah milik negara yang diperuntukkan untuk ruang fungsi lindung yang termasuk kawasan perlindungan. Hal ini sesuai dengan Pasal 68 angka 1 huruf b Undang-Undang Nomor 26 Tahun 2007 tentang Penataan Ruang, yaitu: (1) Kawasan perlindungan setempat sebagaimana dimaksud dalam Pasal 65 ayat (1) huruf c, meliputi (1) kawasan sempa dan pantai; (2) sempa dan sungai dan kanal; dan (3) kawasan sekitar waduk/danau/situ.

Dikarenakan banyaknya permukiman kumuh di bantaran sungai, hal tersebut dapat menutup akses publik untuk menikmati sumber daya alam yang terdapat dalam sungai karena sungai merupakan kawasan milik umum yang dapat diakses untuk semua orang. Tetapi karena banyaknya permukiman di bantaran sungai, maka akses masyarakat yang tidak tinggal di daerah tersebut akan kesusahan untuk mengunjungi kawasan tersebut. Selain itu juga masyarakat akan kesusahan untuk memanfaatkan sumber air di Sungai Ciliwung tersebut karena masyarakat permukiman kumuh selalu membuang sampah di Sungai yang membuat sungai tersebut tercemar dan mengakibatkan bencana seperti banjir. Maka dari itu pemerintah melarang setiap orang untuk membangun tempat tinggal dikawasan-kawasan yang peruntukannya bukan untuk tempat tinggal. Karena dapat menghalangi akses publik yang memang disediakan oleh pemerintah untuk masyarakat umum. Selain itu juga karena daerah bantaran sungai diperuntukkan sebagai kawasan perlindungan dan juga memanfaatkan penataan ruang yang tidak sesuai dengan rencana tata ruang, permukiman kumuh tersebut dapat menghalangi akses terhadap kawasan yang merupakan milik umum.

Penataan ruang menurut Pasal 1 angka 14 Peraturan Daerah Provinsi Daerah Khusus Ibukota Jakarta Nomor 1 Tahun 2012 Tentang Rencana Tata Ruang Wilayah adalah suatu sistem proses perencanaan tata ruang, pemanfaatan ruang, dan pengendalian pemanfaatan ruang. Dalam melaksanakan penataan ruang diarahkan untuk mewujudkan kota yang aman, nyaman, dan tentram bagi masyarakat yang tinggal di daerah Jakarta. Melalui program ini, Kementerian Perumahan Rakyat Republik Indonesia akan melaksanakan peremajaan dan normalisasi Sungai Ciliwung yang perlu dibarengi dengan penataan kawasan pemukiman kumuh dengan cara merelokasi penghuni di bantaran sungai Ciliwung ke suatu lokasi lain yang relatif tidak 
jauh dari lokasi semula secara manusiawi dan memberikan kepastian bermukim. Penataan ruang yang dilaksanakan pemerintah terhadap permukiman kumuh daerah bantaran Sungai Ciliwung tersebut adalah dengan melaksanakan relokasi sebagai sanksi kepada masyarakat yang tinggal didaerah bantaran Sungai Ciliwung.

Jumlah penduduk yang akan dipindahkan mencapai 30.000 kepala keluarga. Meliputi kelurahan Manggarai, Matraman, Bukit Duri, Tebet, Kebon Baru, Cawang, Kalibata dan Rawajati. Kementerian Perumahan Rakyat Republik Indonesia merencanakan membuat sodetan pada Kali Ciliwung di Kebon Baru sepanjang 240m dan di Kalibata sepanjang 260m yang akan menghasilkan tanah baru di atas lahan bekas sungai lama sepanjang 750m di Kebon Baru dan 1670m di Kalibata yang nantinya dapat dimanfaatkan sebagai lokasi wisata atau taman.

Sungai Ciliwung sebagai salah satu sungai penting di Jakarta, tidak luput dari usaha normalisasi. Sungai ini memiliki peran penting sebagai fasilitas penampung dan penyalur air karena mengalir melalui tengah kota Jakarta. Jalur asli dari sungai ini melewati daerah Cikini, Gondangdia, hingga Gambir. Saat ini, aliran Ciliwung melewati daerah Manggarai melalui Kanal Banjir Barat lalu membelok ke Tanah Abang, Tomang, Jembatan Lima, hingga ke Pluit. Pengerjaan normalisasi sungai Ciliwung dilakukan oleh Balai Besar Wilayah Sungai Ciliwung-Cisadane (BBWSCC).

Selain bersih, Sungai Ciliwung di daerah Kampung Pulo dijadikan tempat wisata air seperti arum jeram sebagai bentuk lahan pekerjaan agar dapat memulihkan kondisi ekonomi. Kelurahan selain Kampung Pulo seperti daerah Manggarai, Matraman dan Bukit Duri sudah dilaksanakan relokasi ke rumah susun yang disediakan oleh Pemerintah Ibukota Jakarta. Meskipun tidak semua masyarakat kelurahan Bukit Duri setuju dengan rumah susun yang disediakan oleh pemerintah, tetapi sekarang sudah tidak adalagi masyarakat yang tinggal di daerah rumah susun tersebut. Mereka lebih memilih untuk tinggal bersama kerabat maupun saudara dibanding tinggal di rumah susun yang disediakan oleh pemerintah dengan alasan jarak yang jauh dari rumah susun ke tempat mereka bekerja. Masyarakat mendukung kebijakan pemerintah untuk menormalisasi Sungai Ciliwung tapi perlu ditegaskan mengenai ganti kerugian yang akan diberikan kepada masyarakat agar mengedepankan asas kemanusiaan sesuai dengan Peraturan Daerah Provinsi Daerah Khusus Ibukota Jakarta Nomor 1 Tahun 2012. Sehingga Sungai Ciliwung saat ini sudah tidak sempit seperti dahulu dan kembali berfungsi normal penduduk yang tinggal di daerah tersebut sudah pindah ke rumah susun.

Rumah susun yang disediakan oleh pemerintah Ibukota Jakarta adalah bentuk kerjasama pembangunan antara pemerintah Ibukota Jakarta dan Kementerian PUPR (Pekerjaan Umum dan Perumahan Rakyat. Rumah susun atau rusun merupakan solusi perumahan ibu kota yang dibangun oleh Pemerintah Provinsi DKI Jakarta agar warga mendapatkan tempat tinggal yang layak huni. Pembangunan rusun saat ini juga berfungsi sebagai fasilitas warga yang terkena dampak relokasi. Baik relokasi yang dilakukan untuk mendukung program normalisasi sungai, maupun relokasi 
pemukiman tak layak huni yang berada di tanah negara, di pinggir rel yang berpotensi mengganggu keamanan transportasi kereta, atau di daerah bantaran sungai.

Untuk mendukung proses normalisasi, pemerintah secara khusus menargetkan pembangunan 50.000 unit rusun yang disediakan untuk merelokasi warga Jakarta yang tinggal di kawasan normalisasi Ciliwung. Jika proses pengembalian fungsi sungai Ciliwung berhasil, diharapkan air hujan akan tertampung dan mengalir dengan baik sehingga Jakarta tidak lagi menjadi kota langganan banjir. Selain itu, kawasan sungai Ciliwung yang legendaris dan memiliki sejarah panjang ini juga ditargetkan menjadi tujuan wisata. ${ }^{13}$

Sungai Ciliwung yang mengaliri Jakarta dahulunya terkenal dengan sungai yang penuh dengan sampah, terutama sampah rumah tangga. Banyaknya bangunan liar yang berada di pinggiran sungai adalah penyebab utama pencemaran sungai. Setelah dilakukan penggusuran pemukiman di Kampung Pulo, Jakarta Timur, beberapa waktu lalu dengan disertai bentrokan antara Satpol PP dan aparat Pemerintah Provinsi (Pemprov) DKI Jakarta dengan warga kampung Pulo. Tujuan penggusuran tak lain ialah mewujudkan cita-cita Pemprov DKI untuk melakukan relokasi sungai ciliwung. Kini setelah proses relokasi selasai, warga ibu kota dapat melihat dan merasakan perubahan positif keadaan Sungai Ciliwung sebelum dan sesudah adanya penertiban. ${ }^{14}$

\section{KESIMPULAN}

Berdasarkan Undang-Undang Nomor 2 Tahun 2012 tentang Pengadaan Tanah Bagi Pembangunan Untuk Kepentingan Umum, relokasi permukiman bantaran Sungai Ciliwung yang dilaksanakan oleh Pemerintah Provinsi Jakarta sesuai dengan undangundang pengadaan tanah untuk kepentingan umum. Terdapat dalam Pasal 3 UndangUndang Nomor 2 Tahun 2012 bahwa pengadaan tanah bertujuan untuk menyediakan tanah bagi pelaksanaan pembangunan guna meningkatkan kesejahteraan dan kemakmuran bangsa, negara dan masyarakat dengan tetap menjamin kepentingan umum. Pelaksanaan relokasi merupakan bentuk pengadaan tanah yaitu memindahkan penduduk yang tinggal di bantaran Sungai Ciliwung ke rumah susun sebagai bentuk ganti kerugian yang diberikan pemerintah meskipun mereka melanggar tinggal di tanah negara. Pemerintah menggunakan asas-asas dan prinsip relokasi dalam melaksanakan relokasi sehingga fungsi Sungai Ciliwung dapat kembali normal dan agar masyarakat mendapatkan tempat tinggal yang lebih layak dan memiliki prasarana dan sarana yang memadai.

Dengan adanya pelaksanaan relokasi permukiman kumuh di bantaran Sungai Ciliwung yang dilaksanakan oleh Pemerintah Provinsi Jakarta, sesuai dengan Peraturan Daerah Provinsi Daerah Khusus Ibukota Jakarta Nomor 1 Tahun 2012 Tentang Rencana Tata Ruang Wilayah. Karena penduduk yang dahulu tinggal di bantaran sungai sudah

13 Ibid, at 1.

14 Maria Umma Dewi. 2017, Dulunya Tercemar Kini Sungai Ciliwung Telah Resmi Menjadi Tempat Ekowisata. Dalam https://www.goodnewsfromindonesia.id/2017/09/05/dulunya-tercemar-kini-sungai-ciliwungtelah-resmi-menjadi-tempat-ekowisata. diakses pada 18 Desember 2017 pukul 16.02 WIB. 
tinggal ditempat yang sesuai dengan RTRW Ibukota Jakarta yaitu rumah susun yang disediakan pemerintah daerah dan Kementerian Pekerjaan Umum dan Perumahan Rakyat dan Sungai Ciliwung berfungsi normal sehingga tidak menyebabkan banjir. Terbukti dengan berhasilnya pelaksanaan relokasi di beberapa Kelurahan dan Sungai Ciliwung yang sudah bersih digunakan sebagai tempat wisata air yang dapat membantu kondisi ekonomi warga. Sehingga seluruh warga mempunyai prasarana dan sarana yang berkualitas dan diarahkan untuk mewujudkan visi Jakarta sebagai Ibukota Negara Kesatuan Republik Indonesia yang aman, nyaman, produktif, berkelanjutan, sejajar dengan kota-kota besar dunia dan dihuni oleh masyarakat yang sejahtera.

Berdasarkan pada permasalahan dan kesimpulan yang telah dikemukakan diatas, maka dapat diberikan saran agar masyarakat hendaknya memilih tempat tinggal yang memiliki prasarana dan sarana yang baik agar mempunyai kehidupan yang aman, nyaman dan tentram. Agar tidak mengganggu fungsi tata ruang yang sudah diatur oleh pemerintah daerah dalam peraturan daerah yang berlaku. Selain itu jugaasyarakat hendaknya memilih tempat tinggal diatas tanah yang memang diperuntukkan untuk permukiman, bukan diatas tanah bantaran sungai yang diperuntukkan untuk kepentingan umum. Sedangkan saran untuk pemerintah hendaknya menghimbau masyarakat agar tidak memilih untuk tinggal diatas tanah yang bukan diperuntukkan sebagai tempat tinggal dan menyediakan lahan pekerjaan agar masyarakat mempunyai kebutuhan ekonomi yang cukup sehingga mereka tidak perlu tinggal di tanah negara yang peruntukannya bukan untuk tempat tinggal.

Dalam pelaksanaan relokasi permukiman, pemerintah harus melaksanakan sesuai asas-asas yang tercantum dalam undang-udang dan memberi ganti rugi kepada masyarakat yang mengedepankan asas kemanusiaan dan asas keadilan agar masyarakat yang tinggal di rumah susun setelah pelaksanaan relokasi mendapatkan kehidupan yang lebih layak.

\section{DAFTAR PUSTAKA}

Achmad Rubaie, Hukum Pengadaan Tanah Untuk Kepentingan Umum (Surabaya: Bayumedia, 2007).

Christy Vidiyanti, Studi Kasus: Bantaran Sungai Ciliwung Segmen Kampung Melayu Sustainable Waterfront Develepmont sebagai Strategi Penataan Kembali Kawasan Bantaran Sungai (2014) ITB,Sekolah Arsitektur, Perencanaan, dan Pengembangan Kebijakan.

Fakhrudin Martanto dan Saut Aritua H, Tata Cara Pelaksanaan Penataan Kawasan Relokasi (Jakarta: Dirjen Cipta Karya Kementerian Pekerjaan Umum, 2014)G Kartasapoetra, Jaminan UUPA Bagi Keberhasilan Pendayagunaan Tanah (Jakarta: Rineka Cipta, 1991).

Jakarta Smart City, Rumah Susun dan Normalisasi Ciliwung, dalam http://smartcity.jakarta.go.id/blog/123/r umah-susun-dan-normalisasi-ciliwung (2014). 
Maria Umma Dewi, Dulunya Tercemar Kini Sungai Ciliwung Telah Resmi Menjadi Tempat Ekowisata, dalam https:/www.goodnewsfromindonesia.id/2017/09/05/dulunyatercemar-kini-sungai-ciliwung-telah-resmi-menjadi-tempat-ekowisata (2017).

Nurus Zaman, Politik Hukum Pengadaan Tanah Antara Kepentingan Umum dan Perlindungan Hak Asasi Manusia (Bandung: Refika Aditama, 2016)

Undang-Undang Dasar Negara Republik Indonesia Tahun 1945.

Undang-Undang Nomor 5 Tahun 1960 tentang Peraturan Dasar Pokok-Pokok Agraria. Undang-Undang Nomor 26 Tahun 2007 Tentang Penataan Ruang. Undang-Undang Nomor 1 Tahun 2011 Tentang Perumahan dan Kawasan Permukiman.

Undang-Undang Nomor 2 Tahun 2012 Tentang Pengadaan Tanah Bagi Pembangunan Untuk Kepentingan Umum.

Undang-Undang Nomor 23 Tahun 2014 Tentang Pemerintahan Daerah.

Peraturan Pemerintah Nomor 38 Tahun 2011 Tentang Sungai.Unit Jaringan Dokumentasi dan Informasi Hukum BPK RI Perwakilan Provinsi Kepulauan Bangka Belitung, dalam http://pangkalpinang.bpk.go.id/wpcontent/uploads /2014/12/FUNGSI-SOSIAL-HAK-ATAS-TANAH.pdf (2014)

Peraturan Pemerintah Nomor 14 Tahun 2016 Tentang Penyelenggaraan Perumahan Dan Kawasan Permukiman.

Peraturan Daerah Provinsi Daerah Khusus Ibukota Jakarta Nomor 1 Tahun 2012 Tentang Rencana Tata Ruang Wilayah 2030.

Wayan Suandra, Hukum Pertanahan Indonesia (Jakarta: Rineka Cipta, 1994). 
306 | Relokasi Permukiman Warga Bantaran Sungai Ciliwung di Provinsi Jakarta

This page is intentionally left blank 